\title{
Earthquake in Nepal in 2015 and its effects on school children
}

\author{
Kamal Gautam, PhD \\ Faculty of Education, Tribhuvan University, Kirtipur, Nepal (Email: kamalgautamktm@gmail.com) \\ DOI: $10.31364 /$ SCIRJ/v6.i7.2018.P0718557 \\ http://dx.doi.org/10.31364/SCIRJ/v6.i7.2018.P0718557
}

\begin{abstract}
This research article entitled 'Last earthquake in Nepal and its effects on school children' was carried out after three months period (July to August, 2015) of massive earthquake. The study involved four different community and private schools of Kathmandu valley and 124 respondents consisting students and headmasters. The study tried to find out the effects of earthquake in the families, schools and identify health/ emotional problem in students due to earthquake along with management aspect of relevant schools to mitigate problems occurred due to earthquake. Purposive sampling was used for selecting both schools and respondents.
\end{abstract}

Key Words: earthquake, disaster, effects, health and emotional problems, community and private schools, dropouts, management

\section{Introduction}

In April 2015, an unexpected natural disaster 'earthquake' occurred in Nepal and killed more than 8,000 people and injured more than 21,000. It happened at 11:56 AM (Nepal Standard Time on 25 April) with a magnitude of 7.8 Mw. Its epicenter was on east of Gorkha District at Barpak, and its hypocenter as reported by was at a depth of approximately $8.2 \mathrm{~km}(5.1 \mathrm{mi})$. A series of aftershocks began immediately after the main shock, at intervals of 15-30 minutes, with one aftershock reaching 6.6M within 34 minutes of the initial quake. A major aftershock of magnitude $6.9 \mathrm{M}_{\mathrm{w}}$ occurred on 26 April 2015 in the same region at 12:54 NST (07:08 UTC), with an epicenter located about $17 \mathrm{~km}$ (11 mi) south of Kodari, Nepal (Kim Hjelmgaard, 2015). The aftershock caused fresh avalanches on Mount Everest and was felt in many places in northern India including Kolkata, Silguri, Jalpaiguri, and Assam. The aftershock caused a landslide on the Koshi Highway which blocked the section of the road between Bhedetar and Mulghat (The Indian Express, 2015).

A model of Geogateway, based on a United State Geological Survey mechanism of a near-horizontal fault as well as location of aftershocks showed that the fault had an $11^{\circ}$ dip towards the north, striking at $295^{\circ}, 50 \mathrm{~km} \mathrm{(31} \mathrm{mi)} \mathrm{wide,} 150 \mathrm{~km}(93 \mathrm{mi})$ long, and had a dip slip of $3 \mathrm{~m}$ (9.8 ft.) (IRIS, 2015). The USGS says the aftershock registered at a shallow depth of $10 \mathrm{~km}$ (The Indian Express, 2015). Assuming that 25 April earthquake was the largest event in this seismic episode, Nepal could expect more than 30 aftershocks greater than magnitude 5 over the following month (Nature news, 2015). As of 24 May 2016, 459 aftershocks had occurred with different epicenters and magnitudes equal to or above $4 \mathrm{M}$ (out of which 51 aftershocks are equal to or above $5 \mathrm{M}$ and 5 aftershocks above $6 \mathrm{M}$ ) and more than 20,000 aftershocks less than $4 \mathrm{M}$ (National Seismological Centre of Nepal, 2015).

This disaster caused the massive human and property loss mainly in seventeen districts of Nepal and partial loss in rest about twenty three districts. It affected Kathmandu valley, the capital city of the country destroying huge loss of property and human population as well. It triggered an avalanche on Mount Everest, killing 21, making April 25, 2015 the deadliest day on the mountain in history and the Langtang valley, where 250 people were reported missing. The earthquake made hundreds of thousands of people homeless with entire villages flattened across many districts of the country. Centuries-old buildings at UNESCO World Heritage sites were also destroyed in the Kathmandu Valley. This damaged some at the Kathmandu Durbar Square, the Patan Durbar Square, the Bhaktapur Durbar Square, the Changu Narayan Temple, the Boudhanath Stupa and the Swayambhunath Stupa. Hundreds of government offices, schools, health service institutions and even private properties of people were damaged by this disaster.

Regarding the loss of education sector of Nepal, the United Nations Office for the coordination of Humanitarian Affairs) Asia and the Pacific (2015), on its report of May 2015 states that thousands of schools have been damaged or destroyed by the 7.8 earthquake on April 25 and the destruction has caused the closure of all Nepalese state-run and private schools for a month to manage the situation. More than 16,000 public and private schools - about half of the country's total have been damaged.

\section{Context after three months period}

Three months after Nepal's April 25 earthquake and its aftershocks, children continue to face multiple risks as their families have been pushed deeper into poverty and they remain in need of aid. Although the humanitarian situation has improved over the past three months, hundreds of thousands of children still need shelter, food, access to water and sanitation, medical care, education and protection. About 1 million children affected by the earthquakes continue to live in areas at high risk of landslides and floods. As 
the rainy season takes hold, access to these areas is becoming increasingly challenging, threatening these children's access to water, sanitation, education and health services and putting them at a higher risk of exploitation and abuse, including trafficking. More than 10,000 children have been identified as acutely malnourished since the first earthquake. These include more than 1,000 children with severely acute malnutrition. Over 200 children remain without a parent or caregiver, and more than 600 have lost one or both of their parents to the quakes. Over 32,000 classrooms have been destroyed. Nearly 900,000 houses have been damaged or destroyed (UNICEF, 2015).

According to a Government-led assessment, between 700,000 and almost 1 million people in the worst-affected districts could be pushed below the international poverty line of US\$1.25 a day. "When a major disaster strikes like the earthquakes on 25 April and 12 May, it incurs not only loss of lives but also destruction of assets, sources of livelihoods and substantially reduces household income particularly among the most vulnerable population," said Tomoo Hozumi, UNICEF Representative in Nepal (http://reliefweb.int/report/nepal/nepal-earthquake-humanitarian-situation-report-three-months-review-25-july-2015).

According to a statement published by UNICEF- Nepal (2015), people in earthquake affected area are facing really difficult time. Poor households in such areas often resort to harmful coping strategies, such as reducing their food consumption, cutting down their health and education expenditure, and sending their children to work - all of which can have irreversible negative consequences on them and more so on their children. In this regard the country representative of UNICEF to Nepal said that UNICEF is providing $\$ 15$ million worth of direct cash transfers to approximately 330,000 households, including an estimated 450,000 children, in 19 districts most affected by the earthquakes to help address the immediate needs of children and their families affected by the quakes, This support, channeled through existing government social assistance programs, is reaching vulnerable individuals including Dalit children, people with disabilities, widows, the elderly and marginalized ethnic groups.

The earthquake has exposed the fragility of Nepal's progress in terms of poverty reduction. The Country Representative said that "looking beyond immediate relief, one of the priorities for UNICEF is to assist the government to phase in a reliable and predictable form of income support for children and their families. Strengthening and expanding the country's social protection system and improving its responsiveness to shocks will contribute to children's well-being and development during normal times and increase their families' ability to cope in case of future disasters. Since April, as reported by UNICEF- Nepal, it has also been providing a wide range of services to the children and families living in the areas worst hit by the earthquakes including:

a. Procuring 1,000 metric tons of essential supplies including tents, hygiene kits, therapeutic foods, vaccinations and other lifesaving medicines, medical kits, bed nets, newborn packages, and school-in-a-box and early childhood development kits.

b. Helping over 100,000 children to continue their education in UNICEF-supported temporary learning centers.

c. Supplying clean water to over 650,000 people in homes and camp settings.

d. Restoring birthing centers in more than 150 health facilities.

e. Helping intercept 513 children and women from being trafficked or illegally moved out of the country.

f. Providing nearly 30,000 children with psychosocial support to help them recover from their experiences.

The Representative further said that together with the Government and partners, we have been able to achieve a lot in the past 90 days. At the same time, given the enormity of the damages and losses, and the possible impact of the monsoons, there is a lot more to be done to bring a sense of normalcy to the lives of the earthquake survivors especially the most vulnerable amongst them. There are many other institutions including multi-national organizations in Nepal are assisting directly and through the government mechanism but actual report of such assistance is yet to be reported.

\section{Problems caused by earthquake}

The recent earthquakes and numerous aftershocks in Nepal shattered its school system, leaving vulnerable children at risk. This is a disastrous set back in a country with a 66\% literacy rate and where school attendance has risen to $95 \%$ in recent years, up from $64 \%$ in 1990 . And it's especially disastrous for children of poor families who are at high risk for not returning to school, or being exploited during this time of crisis, driven by their lower social status. To mitigate the crisis caused earthquake, the Nepalese government extended a country wide school suspension until further arrangement.

The government schools of Kathmandu valley mostly receive its students from poor family of Kathmandu and the children of temporary residents of its neighboring districts. Most of the economically able families send their children to private schools for better education because these schools are supposed to be good in providing better education in these days.

Researcher intended to study on children of schools of Kathmandu Valley (community and private schools) after three months of first big earthquake attack. Many schools of Kathmandu valley were then temporarily managed but situation of the children was yet to be found. National and International daily newspapers and electronic media were continuously reporting problems faced by school children ranging from temporary to permanent school dropout due to this disaster. This study therefore, was intended to research on them. 


\section{Objectives of the study}

The following objectives were set for this study;

a. To find out the effects of earthquake in the families.

b. To identify number of students being temporary and permanently dropped out due to effect of earthquake in the schools

c. To identify health/ emotional problem in students due to earthquake

d. To observe management aspect of relevant schools to mitigate problems occurred due to earthquake.

\section{Methodology}

\section{Research design}

This study followed descriptive and exploratory research design. This study identified students being affected by earthquake and explored health and emotional problem manifested in them due to earthquake.

\section{Population of the study}

Both boys and girls of the selected school above grade five were taken as the main respondents for this study. The headmasters of the selected schools were also taken to obtain information of temporary to permanent dropout incidence due to earthquake.

\section{Sources of data}

For the purpose of this study, required data was gathered through both primary and secondary sources. Primary data was collected through interview schedule and secondary data were used as review literature on earthquake. TV news and news of national and international newspapers was also taken as sources.

\section{Sampling procedure and sampling size}

Both respective schools located at Kathmandu valley and total number of respondents (both students and headmasters) to be taken for this study purpose was selected by purposive sampling method. Three community schools of different place of Kathmandu valley and one private school were selected for this study purpose. For this purpose, researcher visited individually to all the selected schools and got their permission to conduct study on them. The total size for this study was 124 altogether out of which 120 were the students both boys and girls above five grade and 4 were either the headmaster or representative of school administration.

\section{Study tools}

Interview schedule and observation sheet were used for collecting necessary data for the study. It was focused on general situation of school after earthquake, situation of the families/ rented rooms of the respondents, record of dropout, health and emotional problems appeared in students after earthquake and measures taken by respective schools to mitigate the problems occurred due to earthquake. Observation sheet was used to describe school situation based on objectives of the study.

\section{Validation of tools}

For validation process, fifteen sets of interview schedule and two sets of observation sheet were pretested among the respondents other then finally involved in the study. After filling up the same, necessary correction was made and final sets were developed.

\section{Data analysis and interpretation}

After collecting data required for this study, all the sets of interview schedule and observation sheet were gathered and tabulated under different headings according to theme. The collected data were then tabulated, presented in the tables with explanation. 


\section{Findings}

The study revealed many findings related to earthquake situation, its impact on school children and management aspects of respective schools to mitigate problems. The major findings of the study are as following:

\section{a. Effects in the families}

Out of 120 families, 78 families were found totally affected by earthquake and they were forced to live in a temporary shelters managed by different humanitarian institutions of both inside and outside the country. Out of rest families, 17 were found living with their relatives and rest 25 families were found hardly adjusted in the rented rooms and their own buildings. Out of the total households taken for this study, only 22 students in the valley were the permanent residents of Kathmandu. Other families were found temporarily migrated from neighboring districts in search of casual work, service in private and government institutions and transport section. The students from neighboring districts said that their original residences built in their homeland were also damaged by earthquake.

\section{b. Effects in the schools}

All the selected schools (three community schools and one private boarding school) were found heavily affected by earthquake. All those schools were reported to be closed for almost two months because of not having space to manage class in the school premises. They were only opened after two months with temporary settings managed by different humanitarian institutions. On my observation, two schools had two additional buildings managed by humanitarian institutions through their local club and one school had one additional building of 6 rooms with the assistance of Non-governmental organization and one private school was found managed by itself taking minimal support of the parents. The additional buildings as reported by students were not convenient but noisy and congested to operate classes.

\section{c. Dropout records}

The school administration gave information about temporarily and permanently dropped out students. There were 64 students permanently dropped out because they were not returned to school until the time of study. It was almost 4 months gone after disaster and 28 students were found recently joined their schools after three months period of the incidence. Among others, 28 students were found transferred to either other schools within the valley or schools of their nearby community.

\section{d. Health and emotional problems occurred in students}

Out of total respondents, 26 respondents were found suffered from diarrhea and dysentery after earthquake. They were medicated from health camps managed by different humanitarian institutions. 14 were suffered with viral fever and were under treatment. Among others, 6 were injured by minor injuries and were in normal condition at the time of data collection. According to report of respective schools, 24 students mostly girls (19) were found emotionally disturbed. The school authorities reported that lack of concentration, fear and anxiety and lack of interest in classroom activities and non-participatory attitudes within group of fellows were the characteristics of emotionally disturbed children. However, a very negligible characteristic was noticed at the time of data collection.

\section{e. Management aspect}

Three community school (Nandi Secondary School., Naxal, Durbar High School Ranipokhari and Baluddar secondary School) had extended buildings with financial assistance of donor agencies. The assistance was provided through Indian and Chinese Embassies. The buildings were on the construction process while taking data for this study but classes were managed hardly by respective schools. One private school (Jugal Bording School) of Kapan had managed classes by managing temporary shelters made up of tents and aluminum sheets. Construction was continuing while collecting data but had not received any financial support from outside parties. The founder members of the school were reported to be involved in collecting necessary fund to manage things. Junior level classes were found bit congested due to not having adequate space for children. 


\section{Conclusion}

The earthquake of 2015 caused massive human and property loss in Kathmandu valley and other several places of the country. It made hundreds of thousands of people homeless and also caused massive damage in education sector as well. Destruction of school buildings in the valley had caused schools closed for couple of months. The state had taken initiation to manage classes by taking assistance from different organizations. Within a very short period of massive earthquake, the schools were found operating their classes with difficulties. Incidence of temporary and permanent dropout of students and emotional and health problems appeared in them due to earthquake were obviously the concerns of everyone to be mitigated. The situation still needs counseling and reassurance to children, parents and school personnel to make things easy going on.

\section{Recommendations}

On the basis of findings and conclusion, the following recommendations are made:

a. Awareness on safe precaution measures of earthquake like disaster needs to be arranged in every school to ensure safety in school.

b. Parents and school personnel should be reassured properly to make them comeback to previous position.

c. At least a health mobile camp in each school is needed to identify health problems in students and state assurance is in need for affected students.

d. For emotional problems, every school is recommended to manage counseling services at school in cooperation with counseling agencies. Schools are recommended to manage their daily activities by seeking appropriate assistance to ensure smooth functioning.

\section{References}

Kathmandu- Nepal -fear- loss -and devastation nytimes.com; Retrieved from https://www.google.com.np/ earthquake\%20in\%20nepal

Kim Hjelmgaard (26 April 2015). "Nepal hit by major aftershock as search for quake survivors intensifies". USA Today. Retrieved 26 April 2015.

"Koshi Highway obstructed". ekantipur.com. retrieved from https://www.google.com.np/ earthquake\%20in\%20nepal

Parajuli, R. \&; Kiyono, J. (2015-01-01). "Ground Motion Characteristics of the 2015 Gorkha earthquake, Survey of damage to stone Masonry Structures and structural Field Tests". Earthquake Engineering: 23. Doi: 10.3389/fbuil.2015.00023.

The Indian Express (2015). Death toll rises to 2200 in Nepal earthquake, India resumes rescue ops". The Indian Express. 26 April 2015. Retrieved 26 July 2015.

"Major earthquake hits Nepal". Nature News \& Comment. Retrieved from https://www.google.com.np/ earthquake\%20in\%20nepal

M7.3 - 18km SE of Kodari, Nepal". USGS Earthquake Hazards Program. Retrieved from https://www.google.com.np/ earthquake\%20in\%20nepal

NDTV (2015). "Fresh Tremors in North India, Including Delhi, a Day after Nepal Earthquake". NDTV. 26 April 2015.

"Nepal earthquake: Eerie reminder of 1934 tragedy" Retrieved from https://www.google.com.np/ earthquake\%20in\%20nepal 